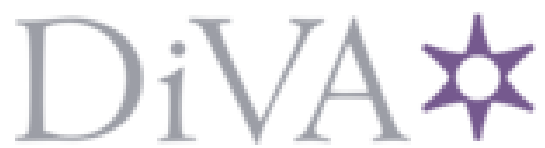

http://www.diva-portal.org

\title{
Postprint
}

This is the accepted version of a paper published in International Journal of Operations \& Production Management. This paper has been peer-reviewed but does not include the final publisher proof-corrections or journal pagination.

Citation for the original published paper (version of record):

Valtakoski, A., Witell, L. (2018)

Service capabilities and servitized SME performance: Contingency on firm age

International Journal of Operations \& Production Management, 38(4): 1144-1164

https://doi.org/10.1108/IJOPM-06-2016-0328

Access to the published version may require subscription.

N.B. When citing this work, cite the original published paper.

Permanent link to this version:

http://urn.kb.se/resolve?urn=urn:nbn:se:kau:diva-66732 


\section{SERVICE CAPABILITIES AND SERVITIZED SME PERFORMANCE: CONTINGENCY ON FIRM AGE}

Purpose: To study the impact of back-office service capability and front-office service capability and how firm age influences the impact of these service capabilities on small and medium size enterprise (SME) performance.

Design/methodology/approach: Based on prior literature on servitization and firm operational capabilities, hypotheses were developed on the impact of service capabilities on firm performance. These hypotheses were tested using a survey and externally sourced financial data on 224 SMEs in the software industry.

Findings: Front-office service capability has a positive impact on firm performance of SMEs. The effect of back-office service capability was weaker and partly contrary to expectations, showing a negative effect on firm performance for young SMEs. As hypothesized, the impact of both back-office and front-office service capability is moderated by firm age. Young SMEs benefit more from front-office service capability. For older SMEs, back-office service capability becomes increasingly more important.

Practical implications: As different capabilities lead to different outcomes, SMEs need to carefully consider which service capabilities to invest in. As the relative importance of capabilities changes over time, SMEs need to be ready to change their strategic focus over time towards back-office capabilities to attain optimal outcomes.

Originality/value: The findings suggest that factors such as industry, firm size and firm age affect the optimal servitization path, and that current understanding of servitization does not necessarily apply to all servitized firms. The study also provides further evidence of the impact of service capabilities on firm performance. 


\section{INTRODUCTION}

Servitization - increasing the role of services - is seen by many product-centric firms as a way to achieve competitive advantage (Gebauer et al., 2011; Lightfoot et al., 2013; Baines et al., 2016). Accordingly, many firms now provide hybrid offerings. These consist of both products and services (Shankar et al., 2009; Ulaga \& Reinartz, 2011), and providing them requires organizational changes, including the development of organizational capabilities "to facilitate the integration of products and services, as well as to develop, sell, and deliver services.” (Paiola et al., 2013: 391). Prior research has sought to identify servitization-related capabilities through explorative research (Ceci \& Masini, 2011; Davies, 2004; Gebauer et al., 2012a; Paiola et al., 2013; Storbacka, 2011; Windahl et al., 2004). Yet, our understanding of these capabilities and their effects on firm performance remains limited (Baines et al., 2016; Ceci \& Masini, 2011).

Three specific gaps can be identified. First, although extant research on servitization and hybrid offerings has suggested various capability categorizations (Davies et al., 2004; Storbacka, 2011; Ceci \& Masini, 2011), there is a paucity of broader, confirmatory samplebased empirical studies. It is also unclear how these capabilities should be measured. This study focuses on service capabilities required by firms with hybrid offerings to successfully provide services (cf. Helfat \& Winter, 2011; Peng et al., 2008). Drawing on literature in operations management (Metters \& Vargas, 2000; Ponsignon et al., 2011) and service management (Larsson \& Bowen, 1989; Grönroos \& Ojasalo, 2004; Mittal et al., 2005), and congruous with recent research on the organizational design of manufacturers in servitization (Raja et al., in press), we differentiate between back-office (BO) service capability related to service activities that do not require direct interaction with customers, and front-office (FO) service capability related to activities that include interaction with customers. 
Second, with rare exceptions (e.g., Ceci \& Masini, 2011; Kohtamäki et al., 2013; Sousa \& Da Silveira, 2017), research on servitization has not directly addressed the impact of capabilities on firm performance. Despite the suggested importance of financial benefits as a motivation for servitization (Raddats et al., 2016), empirical evidence on its outcomes is still scarce (Gebauer et al., 2012b). Moreover, prior research has mostly focused on service revenue share as the main explanatory factor (Kohtamäki et al., 2013; Suarez et al., 2013; Visnjic Kastalli \& Van Looy, 2013), ignoring other potentially important factors such as service capabilities. Our study provides further evidence on this issue by directly studying how service capabilities affect firm performance.

Third, prior research on manufacturing capabilities indicates that capabilities are often interdependent (Wu et al., 2012) and, as suggested by the "sandcone" model, build on each other (Boyer and Lewis, 2002; Rosenzweig and Easton, 2010). Research on servitization commonly suggests that firms should first standardize service processes and establish service platforms (Oliva and Kallenberg, 2003; Reinartz and Ulaga, 2008), implying that BO service capabilities should be developed before FO service capabilities. Yet, empirical evidence suggests some firms opt to first develop customer-facing services and related capabilities (Kowalkowski et al. 2015). Hence, it is not immediately clear what the dependencies are between servitization-related capabilities, what is the relative importance of different service capabilities to firms with hybrid offerings, or which contingencies affect the effectiveness of specific capabilities. To address this issue, we study how the impact of service capabilities is contingent on firm age. Although firm age has an important moderating effect on the outcomes of marketing (Mittal et al., 2005) and innovation activities (Criscuolo et al., 2012), its importance for servitization has not yet been explored.

Based on the identified research gaps, the purpose is to study the impact of back-office service capability and front-office service capability and how firm age influences the impact 
of these service capabilities on firm performance. We focus on small and medium size enterprises (SMEs) - firms with fewer than 250 employees. Typically, SMEs have limited resources, grow rapidly (Smallbone et al., 1995), and undergo significant organizational changes over time (Churchill and Lewis, 1983; Rutherford et al., 2001; Tatikonda et al., 2013). Therefore, understanding how the effectiveness of specific service capabilities depends on firm age would be particularly valuable to firms making investments in capability development (cf. Coltman \& DeVinney, 2013). Moreover, the influence of organizational size is an underdeveloped theme in servitization research (Baines et al., 2016), with only a few prior studies addressing SMEs (Ceci \& Prencipe, 2008; Ceci \& Masini, 2011; Gebauer et al., 2012a). Based on a unique combination of a survey and externally sourced financial data on 224 SMEs in the software industry, our study provides valuable new insights into how service capabilities affect the performance of SMEs with hybrid offerings.

\section{PRIOR RESEARCH ON CAPABILITIES AND SERVITIZATION}

Prior research has established that servitization requires product-centric firms to develop new organizational capabilities related to system integration and service operations (Davies et al., 2006; Miller et al., 2002). Capabilities are firm-level combinations of organizational routines that affect how effectively firms can perform the activities necessary for its business by combining and using available resources (Helfat \& Peteraf, 2003; Peng et al., 2008; Wu et al., 2012), and hence an important part of the operations strategy of a firm (Hitt et al., 2016). In practice, organizational capabilities are manifested in organizational initiatives such as quality management and just-in-time practices (cf. Baines and Lightfoot, 2013; Wu et al., 2012). Prior research clearly indicates that capabilities affect firm performance (Hitt et al., 2016; Tan et al., 2007; Avella \& Vazquez-Bustelo, 2010).

The organizational capabilities perspective has been scarcely applied in servitization research. Extant explorative research has sought to identify capabilities necessary for 
servitization (e.g., Shepherd \& Ahmed, 2000; Möller \& Törrönen, 2003; Davies et al., 2006; Ceci \& Masini, 2006; Ulaga \& Reinartz, 2011; Storbacka, 2011). Only a few authors have studied the direct impact of capabilities on servitized firm performance (cf. Kohtamäki et al., 2013; Sousa \& Da Silveira, 2017). Research provides mostly configurational evidence suggesting that capabilities need to be matched with the characteristics of the competitive environment, offering, and customers (Ceci \& Prencipe, 2008; Ceci \& Masini, 2011; Ulaga \& Reinartz, 2011).

In this study, we focus on operational capabilities (Helfat \& Winter, 2011; Teece et al., 1997; Peng et al., 2008) - capabilities that affect a firm's ability to produce desired outcomes using its current resources, and allow the firm "to earn its living today" (Helfat \& Peteraf, 2003). These capabilities, such as excellence in manufacturing or logistics of goods and services, are crucial to a firm's short-term competitiveness (Hitt et al., 2016; Wu et al., 2012). Based on extant literature, we can differentiate between four types of operational capabilities relevant for hybrid offerings: (1) relational capabilities, such as partnering and network capabilities (Kohtamäki et al., 2013; Möller \& Törrönen, 2003; Shepherd \& Ahmed, 2000; Windahl et al., 2004); (2) product capabilities, such as technical competences and design-forservice capability (Ceci \& Masini, 2011; Ceci \& Prencipe, 2008; Shepherd \& Ahmed, 2000; Ulaga \& Reinartz, 2011); (3) integrative capabilities related to the deployment of integrated solutions (Ceci \& Masini, 2011; Ceci \& Prencipe, 2008; Davies, 2004; Davies et al., 2007; Paiola et al., 2013); and (4) service capabilities related to the development, sales, and delivery of services (Ceci \& Masini, 2011; Ceci \& Prencipe, 2008; Davies, 2004; Davies et al, 2006; Paiola et al., 2013; Storbacka, 2011; Ulaga \& Reinartz, 2011).

Prior research has mostly explored product-related capabilities (Kindström et al., 2013). In contrast, we focus exclusively on service capabilities. These are related to the provision of services requiring interaction between customers and firm employees (Larsson and Bowen, 
1989). For example, airlines need to have sufficient yield management competence. Hospitals need expertise in managing patient queues. As product and service businesses require different capabilities (Baines et al., 2009; Bowen and Ford, 2002; Schmenner, 2009), service capabilities are crucial for firms providing hybrid offerings.

The extant literature offers contradictory evidence on the process of servitization and, consequently, on the interdependencies between different capabilities (Kowalkowski et al., 2015). Most studies suggest that firms should first consolidate product-related service capabilities before investing in customer-facing service capabilities (Oliva \& Kallenberg, 2003, Reinartz \& Ulaga, 2008). However, some authors have suggested an opposite order of capability development, first developing capabilities important for the customer interface (Davies et al., 2006). In summary, it is uncertain how different capabilities should be prioritized and what is their relative importance with respect to other contingencies.

Research on servitization has mostly studied incumbent industrial firms in mature markets (Shepherd \& Ahmed, 2000; Storbacka, 2011; Ulaga \& Reinartz, 2011). These mature firms seek to transition to solution business to exploit an existing installed base, which requires the development of service capabilities to complement existing product capabilities (Davies, 2004). By contrast, only limited research exists on servitization and hybrid offerings in small and medium size enterprises (SME) (Ceci \& Masini, 2011; Ceci \& Prencipe, 2008; Gebauer et al., 2012a; Paiola et al., 2012). As SMEs rarely have a significant installed base, face different competitive environments (Tatikonda et al., 2013) and have had less time to develop service capabilities (Helfat \& Peteraf, 2003), the impact of service capabilities in SMEs is likely to differ from larger firms.

\section{CONCEPTUAL MODEL AND HYPOTHESES}

Prior literature on servitization (Paiola et al., 2013; Storbacka, 2011; Ulaga \& Reinartz, 2011) and operational capabilities (Coltman \& DeVinney, 2013; Avella \& Vazquez-Bustalo, 2010; 
Wu et al., 2012) suggests that service capability is not a uniform construct. To further conceptualize service capabilities, we draw on service research, which suggests service business requires balancing two contradictory operational goals: standardization and customization (Grönroos \& Ojasalo, 2004; Rust et al., 2002). This is analogous with the tradeoff between efficiency and flexibility in manufacturing (Boyer and Lewis, 2002; Ebben and Johnson, 2005). Standardization emphasizes cost efficiency while customization emphasizes customer value and increasing revenues through enhanced value creation.

These operational goals need to be aligned with the design of the service system and the organization of service activities (Johansson and Olhager, 2004; Metters and Vargas, 2000; Ponsignon et al., 2011). Operations management literature widely suggests a division between front-office and back-office activities to minimize the impact of customer contact on service production (Chase, 1981; Larsson and Bowen, 1989; Ponsignon et al., 2011). Following Metters and Vargas (2000), we define service activities requiring interaction with customers, such as help desk service or customer employee training, as front-office activities, and conversely activities where customer presence is not required, such as the preparation of products for installation or the design of new help desk procedures, as back-office activities. These two types of service activities are often aligned with organizational structure (Raja et al., in press). However, as Zomerdijk and De Vries (2007) argue, the division of front-office and back-office activities need not follow the organizational structure. Similarly, Safizadeh et al. (2003) used the concepts of front-office and back-office orientation to study service processes, suggesting that these concepts refer to service activity categorization rather than to the organizational structure.

Building on these insights, we propose that service capability has back-office and frontoffice components unrelated with the organizational structure. Back-office (BO) service capability refers to organizational capabilities related to the management of back-office 
service activities within the organizational boundaries of the service provider. BO service capabilities enable successful design and preparation of service system for delivery, and include the ability to anticipate the need for human resources, and the competence in streamlining existing service delivery processes. Front-office (FO) service capability, by contrast, refers to organizational capabilities related to front-office activities and service delivery across the firm-customer interface. FO service capability ensures the successful delivery of services to customers, and includes the ability to listen and understand customer priorities, and competences in quality control during service delivery.

Next, we elaborate on these concepts and develop hypotheses summarized in the conceptual model shown in Figure 1. In summary, we suggest that BO and FO service capability are positively related to firm performance, and that firm age moderates positively the relationship between $\mathrm{BO}$ service capability and firm performance, and negatively the relationship between FO service capability and firm performance.

\section{$<$ FIGURE 1 ABOUT HERE $>$}

\section{Back-office service capability}

We define back-office (BO) service capability as a collection of organizational routines related to back-office service activities including the management of service demand and capacity, service operations, and human resources management (cf. Rust \& Chung, 2006). These facilitate service provision indirectly by developing resources for front-office activities and carrying out necessary supporting activities, and are typically related to a "service factory" type of services, such as fast food restaurants or grocery stores. For manufacturers such as SKF, BO service capability includes ability to modularize services and the development of required technologies for service provision. BO service capability thus affects activities within the organizational boundaries of the service provider and the production and 
operational aspects of service provision (cf. Storbacka, 2011). Specific related organizational practices include human resource management, service blueprinting, service engineering, and operational control of service production.

BO service capability determines how efficiently the firm can use its resources to produce services (cf. Grönroos \& Ojasalo, 2004) by enhancing the productivity and cost efficiency of the firm's service operations (Rust et al., 2002; Rust \& Chung, 2006). Hence, we posit that back-office service capability improves firm performance due to three mechanisms. First, BO service capability enables a firm to produce the same level of services using fewer resources, directly improving the financial performance of the firm. Second, BO service capability enhances the firm's ability to predict service resources usage, hence improving its capacity efficiency (Grönroos \& Ojasalo, 2004), which leads to higher revenue per service resource. Third, BO service capability facilitates service standardization, which further improves efficient resource usage (Hitt et al., 2001) and enables effective upscaling of service operations (Jensen \& Szulanski, 2007). Therefore, we propose:

Hypothesis 1. Back-office service capability has a positive impact on firm performance.

\section{Front-office service capability}

We define front-office (FO) service capability as the collection of organizational routines that directly influence the front-office service activities of the firm across the firm-customer interface, such as service customization and adaptation (cf. Rust \& Chung, 2006; Rust et al., 2002; Gwinner et al., 2005). FO service capability is typically important for "service shop" type of services, such as hospitals, and professional services, as it improves management of interactions with customers in service provision, and improves the servitized firm's ability to create value and deliver high service quality (Grönroos \& Ojasalo, 2004; Calabrese, 2012), and enhances the potential of the firm's service operations to generate revenue (Rust et al., 
2002) through improving customer satisfaction, retaining existing customers, and improving sales to existing customers (Mittal et al., 2005). For manufacturers such as SKF, this means facilitating co-creation activities through interactive tools to determine the value of the hybrid offering for a specific customer. Other specific practices related to FO service capability include customer visits, customer quality improvement and service guarantees.

FO service capability affects how effectively the firm uses its resources to produce services, and improves firm performance through at least three mechanisms: First, FO service capability drives high service quality, which increases customer satisfaction and loyalty, and subsequently improves firm performance (Zeithaml, 2000). Second, FO service capability enhances the adaptability of services to customer requirements (Gwinner et al., 2005), enabling the firm to anticipate customer needs, hence creating customer value and loyalty. Third, FO service capability facilitates service customization, which increases revenue through enhanced customer value generation and capture (Rust et al., 2002; Zeithaml, 2000). These factors increase revenue per service output, improving firm performance. Hence, we posit:

Hypothesis 2. Front-office service capability has a positive impact on firm performance.

\section{Contingency on firm age}

Research on operations management suggests that organizational capabilities are interdependent (Kortmann et al., 2014; Wu et al., 2012). The traditional "sandcone" model argues that advanced manufacturing capabilities build on more basic capabilities, ranging from quality to cost efficiency (Ferdows and De Meyer, 1990). The literature thus suggests a specific sequence of capability development (Hallgren et al., 2011). Prior service research provides similar insights about capabilities; for example, the simultaneous pursuit of both 
higher productivity and revenue expansion negatively influences performance (Rust et al., 2002), at least in the short run (Mittal et al., 2005), suggesting an interdependence between BO and FO service capabilities.

Extant research on servitization commonly suggests that firms should first develop BO service capabilities around existing product capabilities (Oliva and Kallenberg, 2003), followed by transition from basic services towards advanced services that require FO capabilities (Rönnberg Sjödin et al., 2016; Sousa and da Silveira, 2017). However, other authors suggest that firms should instead first develop FO capabilities to enhance the firmcustomer interaction (Davies et al., 2006). For firms with hybrid offerings, this means that the relative importance of service capabilities is likely to depend on contingencies (cf. Ceci and Masini, 2008; Ulaga and Reinartz, 2011), most importantly on firm life-cycle. This is particularly important for SMEs, as these firms typically evolve rapidly in terms of firm size, organizational complexity, organizational structure, and strategies, meaning that the contingency effects of firm age are magnified for these firms (Churchill \& Lewis, 1983; Rutherford et al., 2001; Tatikonda et al., 2013).

Firm age matters for SMEs with hybrid offerings due to three reasons. First, unlike incumbent firms that have a large installed base (Oliva \& Kallenberg, 2003), young firms are unlikely to have such an installed base, and thus cannot yet extend their business with existing customers. Second, due to mutual adaptation in service provision, customer knowledge and expectations of the service change over time (Grönroos \& Ojasalo, 2004; Raddats et al., 2017). Customers become better informed about the firm's service offering, and through experience in service co-production, develop more precise expectations of service performance. Third, through learning-by-doing, the firm's understanding of its service concept improves over time (Goldstein et al., 2002). This implies that older firms are able to replicate their service operations more efficiently (Jensen \& Szulanski, 2007). 
All these factors affect the impact of BO service capability on firm performance. If a firm lacks an installed base, the benefits of higher productivity of services due to high BO service capability are limited. Over time, firms staying in business will build an installed base and increase their service revenue. Hence, older firms benefit more from higher service productivity. Customers' increasing knowledge, along with mutual adaptation and specialization imply that productivity depends increasingly on the efficiency of the firm's service operations, and, therefore, its BO service capability (Grönroos \& Ojasalo, 2004). Increasing knowledge of the service concept amplifies the effects of BO service capability by enabling the firm to replicate an efficient service operation, further enhancing service profitability (Ulaga and Reinartz, 2011). BO service capability also mitigates the negative effects due to possible growth in organizational size and complexity (Tatikonda et al., 2013). Hence, we posit:

\section{Hypothesis 3a. Firm age positively moderates the relationship between back-} office service capability and firm performance; the older the firm, the larger is the impact of back-office service capability on firm performance.

Firm age also influences the impact of FO service capability on firm performance. FO service capability improves the firm's ability to attract new customers and supports a revenueexpansion strategy (Rust et al., 2002), which is crucial for young firms with no prior customers. However, older firms with an existing customer base are less dependent on attracting new customers, reducing the importance of FO service capability over time (cf. Mittal et al., 2005). As customers' knowledge about services improves over time, opportunities to enhance customer value through improved services diminish gradually. The mutual adaptation process between firm and customers clarifies their roles in service production and shifts emphasis to operational efficiency (Grönroos \& Ojasalo, 2004). Improved understanding of the service concept makes services easier to market to customers 
(Jensen \& Szulanski, 2007), reducing the need for FO service capability. In conclusion, we expect the impact of FO service capability to diminish as the firm ages:

Hypothesis 3b. Firm age negatively moderates the relationship between front-office service capability and firm performance; the older the firm, the smaller is the impact of front-office service capability on firm performance.

\section{METHODOLOGY}

\section{Empirical setting}

To control for industry-specific and external factors such as labor intensity that affect SME performance (Dobbs and Hamilton, 2007), we focused on a single industry. We chose the software industry as the empirical context as most software firms provide hybrid offerings (Cusumano, 2008). Software firms such as IBM are often considered pioneers in servitization (Neely, 2009). Accordingly, prior research has studied servitization in the software context (Ceci \& Prencipe, 2008; Suarez et al., 2013). Software firms are typically small and fit the SME definition (fewer than 250 employees or less than 50 million euros in turnover). Given the high-tech nature and low fixed costs of firm start-up, the software industry is turbulent, with frequent entries and exits; therefore, a sample of the industry is likely to include firms of all ages, making it an ideal context for testing the moderating effect of firm age on the relationship between service capabilities and firm performance.

\section{Data collection}

To avoid common method bias, we used two independent data sources: survey data on service capabilities elicited directly from firms and financial data available from an external database. Detailed firm-level data were collected as part of the yearly Finnish software industry survey, and all financial data were acquired from the ORBIS database with a one year time lag. 
The survey covered the entire Finnish software industry, ranging from software product firms to consulting firms, corresponding to NACE codes 6201 (computer programming activities) and 6202 (computer consultancy activities). The population of firms, identified from both governmental and private registries, consisted of 5341 software firms. However, to ensure that the included firms were large enough to face organizational challenges in service provision, making organizational service capabilities relevant, we applied the thresholds of a minimum of two employees and total revenue of at least 100,000 euros. These two criteria reduced the effective population to 753 firms.

The firms were contacted by both letter and e-mail. The respondent was typically the CEO, the chairman of the board, or a member of the top management team. To improve response rate, we made several reminder phone calls and sent follow-up e-mail messages to the firms (cf. Frohlich, 2002). After excluding incomplete answers, we had 264 usable observations, corresponding to a response rate of 35 percent, in line with survey-based research in operations management (Frohlich, 2002). Three firms in our sample had more than 250 employees. To conform to common SME definition, we excluded these observations from further analysis.

To align our study with research on servitization, we only included firms providing their own services and software products. We reviewed the respondents' descriptions of the firms' business and excluded three types of firms from further analysis: (1) manufacturers of devices with embedded software, (2) resellers of software products, and (3) firms not in the software business. To further ensure compatibility with servitization research, we excluded firms who only served consumers, such as mobile game developers (cf. Cusumano, 2008; Suarez et al., 2013).

The final sample after these exclusions was 224 observations. Following Armstrong and Overton (1977), we assessed the potential impact of nonresponse bias in our data by 
comparing early respondents to late respondents. There were no statistically significant differences between early and late respondents, indicating that nonresponse bias was not a major issue. The descriptive statistics of the sample are shown in Table 1.

\section{$<$ TABLE 1 ABOUT HERE $>$}

\section{Measures}

The measures used in the empirical study and their data sources are shown in Table 2. Wherever possible, we used existing measures for the dependent, moderator and control variables. However, no ready scales existed for service capabilities constructs, which prompted the development of new scales.

\section{$<$ TABLE 2 ABOUT HERE $>$}

Independent variables: Back-office and front-office service capability. Prior literature provides categorizations of servitization-related capabilities, but does not specify how they should be operationalized. Therefore, as advocated by scale development guidelines (Hinkin, 1995), we conducted a qualitative pre-study of nine software firms to understand how SMEs perceive service capability and how it affects their organizations and firm performance. Specific interview topics included firm service offering, characteristics of the firm's products, competences related to services, and the perceived organizational effects of service provision.

Comparing the findings of this pre-study with the theoretical insight of the twodimensional service capability construct, we developed statements similar to previous operationalizations of capabilities in operations management (cf. Chen et al., 2015) that covered both $\mathrm{BO}$ and FO service capability. To improve face validity, we asked five academic researchers to assess these statements for exact wording and necessity of items, and revised 
and removed statements accordingly. Ultimately, we used four items for each service capability construct.

For BO service capability, the statements were: (S1) We have precisely defined service processes; (S2) We can forecast the usage of human resources required by our services; (S3) Our service documentation allows new employees to quickly learn required skills; and (S4) The outcomes of our services depend strongly on the delivering employees (reversed). The following four statements were used for FO service capability: (S5) It is easy for us to communicate with our customers about our services; (S6) We find the pricing of services difficult (reversed); (S7) We can maintain a constant level of service quality; and (S8) We can guarantee the success of our services to our customers. All items were measured using fivepoint Likert scales with anchors "strongly disagree" and "strongly agree."

Dependent variable: Return on sales (ROS). We used profitability as our measure of firm performance. More specifically, we used return on sales (ROS), measured as the ratio of yearly profits or losses (EBIT) to total sales, using data from the ORBIS database. The financial performance of SMEs varies greatly, since these firms often experience high uncertainty and rapid development of their organization and business (Gilbert et al., 2006). Many young firms also invest strategically in product or service development and forgo the generation of current revenue through service provision, resulting in poor profitability immediately following their founding. For these reasons, we inspected the performance data for outliers. We checked the distribution of the dependent variable, and excluded observations with ROS more than four standard deviations from the mean (cf. Hair et al., 2006), leading to the exclusion of three observations with ROS below -1 . 
Moderator: Firm age. We included firm age both as a moderating and control variable, since prior research indicates that firm age affects firm performance (e.g., Galbreath \& Galvin, 2008). Firm age was measured as the difference in years between the founding year and the survey date. The distribution of this variable was right-skewed, so we used a logarithmtransformed version of the variable in further analysis. Since firm age was also a moderator in regression analysis models, it was mean-centered.

Control variables. We included additional variables to control for firm characteristics that potentially affect firm performance. These variables were firm size, firm type, service revenue share, business diversity, and R\&D intensity.

Firm size influences firm performance; for example, firm size generally reflects the extent of the firm's resources (Rust et al., 2002). Hence, we controlled for this factor, measuring firm size in terms of total yearly sales. We considered alternative measures for firm size, such as number of employees and total assets. However, the correlation between these measures and total sales was high, 0.961 and 0.963 , respectively; therefore, these measures were effectively interchangeable, and we chose total sales as measure of firm size. The distribution of this variable was right-skewed, prompting us to use a logarithmtransformed version of the variable in further analysis.

The sample comprised two types of software firms: (1) product firms and (2) service firms (cf. Cusumano, 2008). Software product firms generate most of their revenue from the sales of licensed or web-provided standardized software products, while service firms generate most of their revenue by selling their software-related professional services. Because these two types of firms have different operational logics (Bowen \& Ford, 2002), we controlled for firm type using a dummy variable based on a self-reported firm type. This 
variable was coded as 0 if the firm reported to be a software product firm and 1 if it reported to be a software service firm.

The composition of software firm offering varies greatly in terms of products and services (Cusumano, 2008). Because these differences are unrelated to firm type but affect firm performance (Suarez et al., 2013), we included a measure of the extent of the firms' service offering as a control variable. Based on firm's self-reported revenue breakdown, we measured each firm's offering composition as the ratio of service revenues to total sales. Service revenue was measured as total revenue minus product revenue, which included all product-like revenue elements, such as software-as-a-service and maintenance fees, and excluded all employee-delivered services.

Business diversity affects firm performance (Nath et al., 2010). Therefore, we controlled for the diversity in each firm's business using the Blau-Herfindahl index $1-\sum_{i} r_{i}^{2}$ (cf. Harrison and Klein, 2007), where $r_{i}$ are the revenue shares of product sales, software-asa-service sales, maintenance sales, and other service sales. As the impact of diversity is typically curvilinear (Palich et al., 2000), we also added a square of the diversity as another control variable. To decrease the possible impact of multicollinearity, we used a centralized version of diversity in further analyses.

Prior studies indicate that offering composition in terms of service revenue share may have a curvilinear relationship with firm performance (e.g., Suarez et al., 2013; Visnjic Kastalli \& Van Looy, 2013). However, as our measure of diversity is by definition linearly related to the square of service revenue share, we excluded this additional square term.

$R \& D$ intensity varies greatly between and within industries. $R \& D$ investments tend to have a short-term negative impact on current profitability, while increasing sales and improving profitability in the long run. Therefore, we included R\&D intensity, measured as the ratio of $R \& D$ costs to total sales, as a control variable. Since young firms often make 
considerable R\&D investments before they begin to generate sizable sales, their R\&D intensity can be very high. The variable indeed had significant outliers, leading us to Winsorize 2.5 percent of the observations (total of five observations) at each tail of the distribution (cf. Tatikonda et al., 2013). The Winsorized version of R\&D intensity had a correlation of 0.93 with the original variable.

\section{Reliability and validity of the service capability scales}

Exploratory factor analysis (EFA) of the service capability scales indicated that the data supported a model with two factors. However, item S6 proved to be problematic. Its correlation with all other items was low (factor loading below 0.3). Because three further items were available for the construct, we omitted the item from further analysis. This improved the factor loadings in EFA, and made the scales behave as expected.

Next, we assessed the reliability of the service capability scales. The Cronbach alphas of the $\mathrm{BO}$ and FO service capability were 0.60 and 0.67 , respectively, in line with recommendations for explorative research (Nunnally, 1978) and similar to previous studies on servitization (cf. Gebauer et al., 2011). Moreover, Van de Ven and Ferry (1980) argue that for a scale of three items, alpha should fall between 0.55 and 0.70 for a moderately broad construct. Given that the service capability constructs were conceptually broad, we concluded that the scales showed sufficient reliability to warrant further analysis. Cronbach alphas are also often lower in studies of SMEs (cf. Gustafsson et al., 2003). Our data is consistent with this notion, as Cronbach alphas of service capability scales for firms employing 10 or more were greater $(0.70$ and 0.72$)$ than for those employing fewer than 10 employees $(0.53$ and $0.62)$

To demonstrate discriminant validity of the two service capability scales, we conducted a CFA with both one-factor and two-factor models. The one-factor model fit indices (CFI 0.683, RMSEA 0.167, SRMR 0.106) were much worse than of the two-factor model (CFI 
0.974, RMSEA 0.050, SRMR 0.052), suggesting that the two-factor model had better fit with our data. These indices were also within the suggested cutoff values (Hu \& Bentler, 1999), further supporting the two-factor model. Descriptive statistics and correlations of the variables are shown in Table 3.

\section{$<$ TABLE 3 ABOUT HERE >}

\section{RESULTS}

We used hierarchical ordinary least squares (OLS) regression to test our hypotheses. Hypotheses 1 and 2 were tested as the main effects of BO and FO service capabilities on firm performance. Hypotheses $3 \mathrm{a}$ and $3 \mathrm{~b}$ with firm age as moderator were tested using interaction terms. We performed the analysis for ROS in a stepwise fashion, adding first the control variables (Model 1), then the main effects (Models 2a-2c), and finally, the interaction terms (Model 3). The results of the regression analyses are shown in Table 4. The explanatory power of the full regression model, measured with adjusted $R^{2}$, was 0.178 , comparable to prior research using similar measures of performance (Carr and Pearson, 2002).

\section{$<$ TABLE 4 ABOUT HERE $>$}

Models $2 \mathrm{~b}$ and $2 \mathrm{c}$ strongly supported Hypothesis 2 , the positive impact of FO service capability on firm performance. However, contrary to Hypothesis 1, the coefficient of BO service capability was negative and nonsignificant in models $2 \mathrm{a}$ and $2 \mathrm{c}$, which suggests that BO service capability does not have a positive impact on firm performance. We elaborate on this unexpected result in the discussion section.

Model 3 tested the moderating effect of firm age on the relationship between service capability and firm performance. We found support for both Hypotheses $3 \mathrm{a}$ and $3 \mathrm{~b}$; that is, firm age positively moderates the impact BO service capability on ROS and negatively 
moderates the impact of FO service capability on ROS. Adding interaction terms also noticeably improved the overall model fit. As we had taken precautions to mitigate multicollinearity between variables, its effects were negligible. In the final model, variance inflation factors (VIFs) of all coefficients were under 2.5, well under suggested threshold of 10 (Hair et al., 2006), leading us to conclude that multicollinearity was not an issue.

To interpret the interaction terms, we plotted the relationship between $\mathrm{BO}$ and $\mathrm{FO}$ service capability and ROS at three values of firm age: mean-SD, mean, and mean+SD of the log-transformed firm age. These correspond to firm ages of 3.0, 7.6 and 17.3 years, respectively. The plots, shown in Figure 2, reconfirm our conclusions: firm age has a positive and negative moderating effect on the relationship between firm performance and BO and FO service capability, respectively. The plots indicate differences in the behavior of firm age moderation: the effect of BO service capability changes more rapidly, while FO service capability effects changes slower and takes longer to change sign.

$<$ FIGURE 2 ABOUT HERE $>$

\section{DISCUSSION}

Our findings provide new insights into how service capabilities affect the performance of SMEs providing hybrid offerings. We found support for the hypothesized positive relationship between FO service capability and firm performance. However, the effects of BO service capability were contrary to our expectations. We found a negative relationship between BO service capability and firm performance, suggesting that high BO service capability can be detrimental for SME performance. Importantly, we also found that firm age moderates the impact of both $\mathrm{BO}$ and FO service capability on firm performance. 


\section{Implications for research}

Our findings extend prior research on servitization in several ways. First, our study adds to the research on capabilities in servitization (Ceci \& Masini, 2011; Ceci \& Prencipe, 2008; Paiola et al., 2013; Storbacka, 2011; Baines et al., 2016) by indicating that service capability is a meaningful construct that can be operationalized and measured at the firm level. Few prior attempts have been made to directly measure service capabilities. In contrast to previous attempts, such as Sousa \& Da Silveira (2017), our results suggest a division of service capabilities into BO and FO service capabilities. The observed opposite effects of these capabilities on firm performance highlight that service capabilities are not homogeneous. It is thus important to use a multidimensional model of service capabilities when studying servitization.

Second, our study provides evidence on the relationship between service capabilities and firm performance. Extant research on how servitization affects firm performance has produced contradictory results (Eggert et al., 2014; Gebauer et al., 2012b). Moreover, prior studies have either studied the impact of generic service strategies on firm performance, using measures such as revenue share of services (Suarez et al., 2013; Visnjic Kastalli \& Van Looy, 2013), or the impact of capabilities indirectly by identifying a fit between firm capabilities and the competitive environment (Ceci \& Masini, 2011; Gebauer, 2008). Few have directly studied the impact of service capabilities. Our findings clearly indicate that service capabilities affect firm performance, irrespective of specific service offering composition or extent of service provision. This suggests that future research should account for organizational capabilities when studying the impact of servitization on firm performance.

Third, our findings indicate that the impact of service capabilities is contingent on other factors. Since it is better to focus on improving only a few operational capabilities at a time (Wu et al., 2012), understanding which service capabilities are important is valuable, 
particularly for SMEs with limited resources. Contrary to most research on servitization (Reinartz and Ulaga, 2008: Oliva and Kallenberg, 2003), we find that young SMEs benefit from having strong FO service capabilities and only later from BO service capabilities. This is in line with research on integrated solutions (Davies et al., 2006). To generalize, the findings suggest that contingencies such as industry, firm size and firm age affect the relative importance of service capabilities, and that further research into the specific effects of these contingencies is needed.

Related, our study also suggests that having the wrong capabilities can have negative performance outcomes (Drnevich and Kriauciunas, 2011). While the negative effects are likely to vanish eventually, SMEs may be stuck with detrimental operational capabilities. For example, if a firm cannot utilize its entire service capacity in service provision, investing in service capability development requires resources that become unavailable for revenue generation (Fang et al., 2008). There might be a misalignment between the current service offering and service capabilities (Ponsignon et al., 2011; Coltman and DeVinney, 2013). An emphasis on internal efficiency may lead to an overly rigid organization and processes, sacrificing the flexibility often required in emerging markets, and reducing firm performance (Ebben \& Johnson, 2005). Since software products have high profitability, putting disproportionate emphasis on BO service capability can distract the firm from a profitable product business. To generalize, future research should investigate under which conditions service capabilities can have negative effects.

Finally, this paper adds to the knowledge on hybrid offerings outside large manufacturing firms (e.g., Gebauer et al., 2010; Baines et al., 2016). As recent research suggests (Löfberg et al., 2015), servitization affects entire supply chains, including SME suppliers, indicating the need to understand the implications of servitization for these firms. Our results reveal that SMEs with hybrid offerings do not necessarily face the same 
challenges as large manufacturers, i.e. there is a need for further research to understand the role of building a service business without an existing installed base.

\section{Implications for managers}

For managers of SMEs with hybrid offerings, and software firms in particular, our study provides guidance on how and when to develop capabilities in service provision. The first managerial insight is that not all capabilities are equal; their impact on performance varies, and can also be negative. Therefore, it is crucial to pay attention to which service capabilities are needed for business to succeed. For example, competences in BO service capability such as service standardization and FO service capability such as customer orientation are unlikely to have similar effects. Moreover, investment in wrong capabilities such as BO service capability in young SMEs can also have negative impact on performance as it can prematurely stifle the firm's services and distract from more profitable activities. As the resources of SMEs are often limited, the choice of where to invest becomes even more important.

The second managerial insight is that the impact of service capabilities depends on other contingencies. Our findings indicate that firm age dictates the relative importance of BO and FO service capabilities. As indicated by other research, other factors such as competitive environment, offering and customer characteristics are also likely to affect the importance of different capabilities (Ceci \& Prencipe, 2008; Ulaga \& Reinartz, 2011). Therefore, it becomes paramount to understand the context of business, and SME managers should carefully study their business environment before investing in service capability development, as emphasizing the wrong capability at the wrong time can render the business unprofitable.

Third, given the importance of firm age as a contingent factor for the importance of service capabilities, our findings suggest that SMEs with hybrid offerings must be prepared to change their service capabilities over time. While change is a constant theme in the existence 
of SMEs, this study highlights the importance of including organizational capabilities as one factor requiring attention throughout the firm life-cycle. The use of a strategic roadmap for building the business, focusing on when to introduce new services and how to develop and invest in various capabilities is a key in building a profitable service business.

More specifically, the fourth insight is that, contrary to commonly suggested in servitization literature, our study shows that SMEs benefit more from first building FO instead of BO service capabilities. Our results suggest that FO service capability is beneficial for recently founded SMEs, since it improves the firm's chances to successfully engage in market-creating activities and to market services to new customers. A practice used by one of the SMEs is to sell service projects, where the first customer helps to pay for the development of the new service - if successful it can turn into a service that can be sold to additional customers. In such a case, the first customer helps the SME to developing and allowing investment in BO service capabilities.

As the firm and its market mature and its customer base grows, the benefits of $\mathrm{BO}$ service capabilities increase. In a mature market, emphasis on internal efficiency is more likely to yield competitive advantage because of increased competition and more established customer relationships. In these cases, practices such as service blueprinting and lean manufacturing can be used to improve efficiency without losing customer focus. This also often involves using information technology to automate back-office processes to improve their reliability and efficiency. Improved process efficiency also provides a cost advantage, allowing the firm to potentially take over customer processes and production responsibilities to further grow the service business.

\section{Limitations and further research}

The main limitations of this paper are related to the empirical setting and data. We acknowledge the problems of making causal inferences from cross-sectional data (Bowen \& 
Wiersema, 1999). A full understanding of the development and impact of service capability on firm performance would require longitudinal data, particularly given our interest in the moderating effects of firm age. Furthermore, this would also allow the direct study of capability evolution and possible influence of dynamic capabilities in the development of servitization related capabilities.

As no ready operationalization of service capabilities was available, we developed novel scales for measuring service capabilities. Although the scales displayed relatively low convergent validity and reliability, consistent with previous exploratory research in SMEs, analysis indicated divergent validity, suggesting that BO and FO service capabilities can be measured independently. In addition, the opposing effects of the two service capabilities in regression analyses suggest the nomological validity of the scales. However, developing better and more comprehensive scales for service capabilities and other servitization related constructs is clearly necessary. Existing scales, such as Gebauer, Witell and Gustafsson (2011) and Sousa and Da Silveira (2017), together with the present research, can serve as a first step in this direction.

A basic assumption in this study was that service capability is a firm-level construct that is homogeneous across different parts of an organization - a reasonable assumption when studying SMEs. However, we expect this assumption to be more problematic for large organizations, particularly when a separate business unit is created for service provision. Therefore, future research could study how service capability varies within firms, and how this variation influences firm performance. Building on this, further research could investigate the potential effects of structure of the service organization, i.e. how the structure of back/front office organization influences the effect on firm performance.

An interesting question raised by our study is whether there is a difference in the characteristics and impact of service capabilities between new SMEs and those transitioning 
from a product-centric business. A comparative case study similar to the study by Jovanic, Engwall and Jerbrandt (2016) would be helpful. A comparative longitudinal multiple case study would increase our understanding of how service capabilities and other firm capabilities interact to influence service business profitability. 


\section{REFERENCES}

Armstrong, S.J. and Overton, T.S. (1977), "Estimating non-response in mailed surveys", Journal of Marketing Research, Vol. 18 No. 3, pp. 396-402.

Avella, L. and Vázquez-Bustelo, D. (2010), “The multidimensional nature of production competence and additional evidence of its impact on business performance", International Journal of Operations \& Production Management, Vol. 30 No. 6, pp. 548-583.

Baines, T. and Lightfoot, H.W. (2013), "Servitization of the manufacturing firm: Exploring the operations practices and technologies that deliver advanced services", International Journal of Operations \& Production Management, Vol. 34 No. 1, pp. 2-35.

Baines, T., Lightfoot, H.W., Peppard, J., Johnson, M., Tiwari, A., Shehab, E. and Swink, M. (2009), "Towards an operations strategy for product-centric servitization", International Journal of Operations \& Production Management, Vol. 29 No. 5, pp. 494-519.

Baines, T., Ziaee Bigdeli, A., F Bustinza, O., Shi, V.G., Baldwin, J. and Ridgeway, K. (2016), "Servitization: revisiting the state-of-the-art and research priorities", International Journal of Operations and Production Management, In press; DOI: 10.1108/IJOPM-06-2015-0312.

Bowen, J. and Ford, R.C. (2002), "Managing Service Organizations: Does Having a 'Thing' Make a Difference?", Journal of Management, Vol. 28 No. 3, p. 447.

Bowen, H.P. and Wiersema, M.F. (1999), "Matching method to paradigm in strategy research: limitations of cross-sectional analysis and some methodological alternatives", Strategic Management Journal, Vol. 20 No. 7, pp. 625-636.

Boyer, K.K. and Lewis, M.W. (2002), “Competitive Priorities: Investigating the Need for Trade-Offs in Operations Strategy”, Production and Operations Management, Vol. 11 No. 1, pp. 9-20.

Calabrese, A. (2012), "Service productivity and service quality: A necessary trade-off?", International Journal of Production Economics, Vol. 135 No. 2, pp. 800-812. 
Carr, A. S., \& Pearson, J. N. (2002), “The impact of purchasing and supplier involvement on strategic purchasing and its impact on firm's performance", International Journal of Operations \& Production Management, Vol. 22 No. 9, pp. 1032-1053.

Ceci, F. and Masini, A. (2011), "Balancing specialized and generic capabilities in the provision of integrated solutions", Industrial and Corporate Change, Vol. 20 No. 1, pp. 91-132.

Ceci, F. and Prencipe, A. (2008), "Configuring capabilities for integrated solutions: evidence from the IT sector", Industry and Innovation, Vol. 15 No. 3, pp. 277-296.

Chase, R.B. (1981), "Customer Contact Approach to Services: Theoretical Bases and Practical Extensions", Operations Research, Vol. 29 No. 4, pp. 698-706.

Chen, Y.-T., Dultra-de-Lima, R.G., Csillag, J.M. and Oyadomari, J.C.T. (2015), "Does the competitive orientation really lead to emphasis on different internal capabilities?", International Journal of Operations \& Production Management, Vol. 35 No. 7, pp. 1075-1096.

Churchill, N.C. and Lewis, V.L. (1983), “The five stages of small business growth”, Harvard Business Review, Vol. 61 No. 3, pp. 30-50.

Coltman, T. and Devinney, T.M. (2013), "Modeling the operational capabilities for customized and commoditized services”, Journal of Operations Management, Vol. 31 No. 7-8, pp. 555-566.

Criscuolo, P., Nicolaou, N. and Salter, A. (2012), "The elixir (or burden) of youth? Exploring differences in innovation between start-ups and established firms", Research Policy, Vol. 41, pp. 319-333.

Cusumano, M.A. (2008), “The Changing Software Business: Moving from Products to Services”, IEEE Computer, Vol. 41 No. 1, pp. 20-27.

Davies, A. (2004), "Moving base into high-value integrated solutions: a value stream approach", Industrial and Corporate Change, Vol. 13 No. 5, pp. 727-756.

Davies, A., Brady, T. and Hobday, M. (2006), "Charting a Path Toward Integrated Solutions", MIT Sloan Management Review, Vol. 47 No. 3, pp. 39-48. 
Davies, A., Brady, T. and Hobday, M. (2007), “Organizing for solutions: Systems seller vs. systems integrator", Industrial Marketing Management, Vol. 36 No. 2, pp. 183-193.

Dobbs, M. and Hamilton, R.T. (2007), "Small business growth: recent evidence and new directions", International Journal of Entrepreneurial Behavior \& Research, Vol. 13 No. 5, pp. 296-322.

Drnevich, P.L. and Kriauciunas, A.P. (2011), "Clarifying the conditions and limits of the contributions of ordinary and dynamic capabilities to relative firm performance", Strategic Management Journal, Vol. 32 No. 3, pp. 254-279.

Ebben, J.J. and Johnson, A.C. (2005), "Efficiency, flexibility, or both? Evidence linking strategy to performance in small firms", Strategic Management Journal, Vol. 26 No. 13, pp. 1249-1259.

Eggert, A., Hogreve, J., Ulaga, W. and Muenkhoff, E. (2014), "Revenue and Profit Implications of Industrial Service Strategies", Journal of Service Research, Vol. 17 No. 1, pp. 23-39.

Fang, E., Palmatier, R.W. and Steenkamp, J.-B.E.M. (2008), “Effect of Service Transition Strategies on Firm Value", Journal of Marketing, Vol. 72 No. 5, pp. 1-14.

Ferdows, K. and De Meyer, A. (1990), “Lasting improvements in manufacturing performance: in search of a new theory", Journal of Operations Management, Vol. 9 No. 2, pp. 168-184.

Fischer, T., Gebauer, H., Gregory, M., Ren, G. and Fleisch, E. (2010), "Exploitation or exploration in service business development?: Insights from a dynamic capabilities perspective”, Journal of Service Management, Vol. 21 No. 5, pp. 591-624.

Frohlich, M.T. (2002), “Techniques for improving response rates in OM survey research”, Journal of Operations Management, Vol. 20 No. 1, pp. 53-62.

Galbreath, J. and Galvin, P. (2008), "Firm factors, industry structure and performance variation: New empirical evidence to a classic debate", Journal of Business Research, Vol. 61 No. 2, pp. 109117. 
Gebauer, H. (2008), “Identifying service strategies in product manufacturing companies by exploring environment-strategy configurations", Industrial Marketing Management, Vol. 37 No. 3, pp. 278-291.

Gebauer, H., Gustafsson, A. and Witell, L. (2011), "Competitive advantage through service differentiation by manufacturing companies”, Journal of Business Research, Vol. 64 No. 12, pp. $1270-1280$.

Gebauer, H., Paiola, M. and Edvardsson, B. (2010), "Service business development in small and medium capital goods manufacturing companies”, Managing Service Quality, Vol. 20 No. 2, pp. 123-139.

Gebauer, H., Paiola, M. and Edvardsson, B. (2012), "A capability perspective on service business development in small and medium-sized suppliers", Scandinavian Journal of Management, Vol. 28 No. 4, pp. 321-339.

Gebauer, H., Ren, G., Valtakoski, A. and Reynoso, J. (2012), "Service-Driven Manufacturing: Provision, Evolution and Financial Impact of Services in Industrial Firms", Journal of Service Management, Vol. 23 No. 1, pp. 120-136.

Gilbert, B.A., McDougall, P.P. and Audretsch, D.B. (2006), "New venture growth: A review and extension”, Journal of Management, Vol. 32 No. 6, p. 926.

Goldstein, S.M., Johnston, R., Duffy, J.A. and Rao, J. (2002), “The service concept: the missing link in service design research?”, Journal of Operations Management, Vol. 20 No. 2, pp. 121-134.

Grönroos, C. and Ojasalo, K. (2004), "Service productivity: Towards a conceptualization of the transformation of inputs into economic results in services", Journal of Business Research, Vol. 57 No. 4, pp. 414-423.

Gustafsson, A., Nilsson, L. and Johnson, M.D. (2003), "The role of quality practices in service organizations", International Journal of Service Industry Management, Vol. 14 No. 2, pp. 232 244. 
Gwinner, K.P., Bitner, M.J., Brown, S.W. and Kumar, A. (2005), "Service Customization Through Employee Adaptiveness", Journal of Service Research, Vol. 8 No. 2, pp. 131-148.

Hair, J., Anderson, R., Tatham, R. and Black, W. (2006), Multivariate Data Analysis, Englewood Cliffs, NJ: Prentice-Hall.

Hallgren, M., Olhager, J. and Schroeder, R.G. (2011), “A hybrid model of competitive capabilities", International Journal of Operations \& Production Management, Vol. 31 No. 5, pp. 511-526.

Harrison, D.A. and Klein, K.J. (2007), "What's the difference? diversity constructs as separation, variety, or disparity in organizations", Academy of Management Review, Vol. 32 No. 4, pp. $1199-1228$.

Helfat, C.E. and Peteraf, M.A. (2003), "The dynamic resource-based view: capability lifecycles", Strategic Management Journal, Vol. 24 No. 10, pp. 997-1010.

Helfat, C.E. and Winter, S.G. (2011), “Untangling Dynamic and Operational Capabilities: Strategy for the (N)ever-Changing World”, Strategic Management Journal, Vol. 32 No. 11, pp. 1243-1250.

Hinkin, T.R. (1995), “A review of scale development practices in the study of organizations", Journal of Management, Vol. 21 No. 5, pp. 967-988.

Hitt, M.A., Bierman, L., Shimizu, K. and Kochhar, R. (2001), "Direct and Moderating Effects of Human Capital on Strategy and Performance in Professional Service Firms: A Resource-Based Perspective", Academy of Management Journal, Vol. 44 No. 1, pp. 13-28.

Hu, L. and Bentler, P.M. (1999), "Cutoff criteria for fit indexes in covariance structure analysis: Conventional criteria versus new alternatives", Structural Equation Modeling, Vol. 6 No. 1, pp. $1-55$.

Jensen, R.J. and Szulanski, G. (2007), “Template use and the effectiveness of knowledge transfer”, Management Science, Vol. 53 No. 11, pp. 1716-1730.

Johansson, P. and Olhager, J. (2004), “Industrial service profiling: Matching service offerings and processes", International Journal of Production Economics, Vol. 89 No. 3, pp. 309-320. 
Jovanovic, M., Engwall, M., \& Jerbrant, A. (2016), "Matching Service Offerings and Product Operations: A Key to Servitization Success", Research-Technology Management, Vol. 59 No. 3, pp. 29-36.

Kindström, D., Kowalkowski, C. and Sandberg, E. (2013), “Enabling service innovation: A dynamic capabilities approach”, Journal of Business Research, Vol. 66 No. 8, pp. 1063-1073.

Kohtamäki, M., Partanen, J., Parida, V. and Wincent, J. (2013), "Non-linear relationship between industrial service offering and sales growth: The moderating role of network capabilities", Industrial Marketing Management, Vol. 42 No. 8, pp. 1374-1385.

Kortmann, S., Gelhard, C., Zimmermann, C. and Piller, F.T. (2014), "Linking strategic flexibility and operational efficiency: The mediating role of ambidextrous operational capabilities", Journal of Operations Management, Vol. 32 No. 7-8, pp. 475-490.

Kowalkowski, C., Windahl, C., Kindström, D. and Gebauer, H. (2015), "What service transition? Rethinking established assumptions about manufacturers' service-led growth strategies", Industrial Marketing Management, Vol. 45 No. 1, pp. 59-69.

Krasnikov, A. and Jayachandran, S. (2008), "The Relative Impact of Marketing, Research-andDevelopment, and Operations Capabilities on Firm Performance", Journal of Marketing, Vol. 72 No. 4, pp. 1-11.

Larsson, R. and Bowen, D.E. (1989), “Organization and customer: managing design and coordination of services", Academy of Management Review, Vol. 14 No. 2, pp. 213-33.

Lightfoot, H., Baines, T. and Smart, P. (2013), "The servitization of manufacturing: A systematic literature review of interdependent trends", International Journal of Operations \& Production Management, Vol. 33 No. 11/12, pp. 1408-1434.

Löfberg, N., Witell, L. and Gustafsson, A. (2015), “Service manoeuvres to overcome challenges of servitisation in a value network", Production Planning \& Control, Vol. 26 No. 14-15, pp. 1188 1197. 
Marinova, D., Ye, J. and Singh, J. (2008), “Do Frontline Mechanisms Matter? Impact of Quality and Productivity Orientations on Unit Revenue, Efficiency, and Customer Satisfaction”, Journal of Marketing, Vol. 72 No. 2, pp. 28-45.

Mathieu, V. (2001), "Product services: from a service supporting the product to a service supporting the client”, Journal of Business and Industrial Marketing, Vol. 16 No. 1, pp. 39-61.

Metters, R. and Vargas, V. (2000), “A typology of de-coupling strategies in mixed services”, Journal of Operations Management, Vol. 18 No. 6, pp. 663-682.

Miller, D., Hope, Q., Eisenstat, R., Foote, N. and Galbraith, J.R. (2002), “The problem of solutions: Balancing clients and capabilities", Business Horizons, Vol. 45 No. 2, pp. 3-12.

Mittal, V., Anderson, E.W., Sayrak, A. and Tadikamalla, P. (2005), "Dual Emphasis and the Long-Term Financial Impact of Customer Satisfaction”, Marketing Science, Vol. 24 No. 4, pp. 544-555.

Möller, K. and Törrönen, P. (2003), “Business Suppliers’ Value Creation Potential: A Capability-Based Analysis", Industrial Marketing Management, Vol. 32 No. 2, pp. 109-118.

Nath, P., Nachiappan, S. and Ramanathan, R. (2010), "The impact of marketing capability, operations capability and diversification strategy on performance: A resource-based view", Industrial Marketing Management, Vol. 39 No. 2, pp. 317-329.

Neely, A. (2009), "Exploring the financial consequences of the servitization of manufacturing", Operations Management Research, Vol. 1 No. 2, pp. 103-118.

Nunnally, J.C. (1978), Psychometric Theory, 2nd ed., McGraw-Hill Companies, New York, NY.

Oliva, R. and Kallenberg, R. (2003), "Managing the transition from products to services", International Journal of Service Industry Management, Vol. 14 No. 2, pp. 160-172.

Paiola, M., Gebauer, H. and Edvardsson, B. (2012), "Service Business Development in Small- to Medium-Sized Equipment Manufacturers”, Journal of Business-to-Business Marketing, Vol. 19 No. 1, pp. 33-66. 
Paiola, M., Saccani, N., Perona, M. and Gebauer, H. (2013), "Moving from products to solutions: Strategic approaches for developing capabilities”, European Management Journal, Vol. 31 No. 4, pp. 390-409.

Palich, L.E., Cardinal, L.B. and Miller, C.C. (2000), "Curvilinearity in the diversification-performance linkage: an examination of over three decades of research", Strategic Management Journal, Vol. 21 No. 2, pp. 155-174.

Peng, D.X., Schroeder, R.G. and Shah, R. (2008), "Linking routines to operations capabilities: A new perspective", Journal of Operations Management, Vol. 26 No. 6, pp. 730-748.

Ponsignon, F., Smart, P.A. and Maull, R.S. (2011), "Service delivery system design: characteristics and contingencies", International Journal of Operations \& Production Management, Vol. 31 No. 3, pp. 324-349.

Raddats, C., Baines, T., Burton, J., Story, V.M. and Zolkiewski, J. (2016), "Motivations for servitization: the impact of product complexity", International Journal of Operations \& Production Management, Vol. 36 No. 5, pp. 572-591.

Raddats, C., Zolkiewski, J., Story, V. M., Burton, J., Baines, T., \& Ziaee Bigdeli, A. (2017). "Interactively developed capabilities: evidence from dyadic servitization relationships", International Journal of Operations \& Production Management, Vol. 37 No. 3, pp. 382-400.

Raja, J.Z., Chakkol, M., Johnson, M., Beltagui, A., (in press). “Organizing for servitization: examining front-and back-end design configurations", International Journal of Operations \& Production Management.

Reinartz, W. and Ulaga, W. (2008), "How to Sell Services More Profitably", Harvard Business Review, Vol. 86 No. 5, pp. 90-96.

Rönnberg Sjödin, D., Parida, V. and Kohtamäki, M. (2016), “Capability configurations for advanced service offerings in manufacturing firms: Using fuzzy set qualitative comparative analysis", Journal of Business Research, Vol. 69 No. 11, pp. 5330-5335. 
Rosenzweig, E.D. and Easton, G.S. (2010), “Tradeoffs in Manufacturing? A Meta-Analysis and Critique of the Literature", Production and Operations Management, Vol. 19 No. 2, pp. 127-141.

Rust, R.T. and Chung, T.S. (2006), "Marketing Models of Service and Relationships”, Marketing Science, Vol. 25 No. 6, pp. 560-580.

Rust, R.T., Moorman, C. and Dickson, P.R. (2002), “Getting Return on Quality: Revenue Expansion, Cost Reduction, or Both?”, Journal of Marketing, Vol. 66 No. 4, pp. 7-24.

Rutherford, M.W., McMullen, P. and Oswald, S. (2001), "Examining the Issue of Size and the Small Business: A Self Organizing Map Approach”, Journal of Business \& Economic Studies, Vol. 7 No. 2, p. 64 .

Safizadeh, M.H., Field, J.M. and Ritzman, L.P. (2003), “An empirical analysis of financial services processes with a front-office or back-office orientation”, Journal of Operations Management, Vol. 21 No. 5, pp. 557-576.

Schmenner, R.W. (2009), "Manufacturing, service, and their integration: some history and theory", International Journal of Operations \& Production Management, Vol. 29 No. 5, pp. 431-443.

Shankar, V., Berry, L. L., \& Dotzel, T. (2009). "A Practical Guide to Combining Products And Services“, Harvard Business Review, Vol. 87 No 1, pp. 94-99.

Shepherd, C. and Ahmed, P.K. (2000), "From product innovation to solutions innovation: a new paradigm for competitive advantage", European Journal of Innovation Management, Vol. 3 No. 2, pp. 100-106.

Smallbone, D., Leig, R. and North, D. (1995), "The characteristics and strategies of high growth SMEs", International Journal of Entrepreneurial Behavior \& Research, Vol. 1 No. 3, pp. 44-62.

Sousa, R. and da Silveira, G.J.C. (2017), "Capability antecedents and performance outcomes of servitization: Differences between basic and advanced services", International Journal of Operations \& Production Management, Vol. 37 No. 4, pp. 444-467. 
Storbacka, K. (2011), “A solution business model: Capabilities and management practices for integrated solutions", Industrial Marketing Management, Vol. 40 No. 5, pp. 699-711.

Suarez, F.F., Cusumano, M.A. and Kahl, S.J. (2013), "Services and the Business Models of Product Firms: An Empirical Analysis of the Software Industry”, Management Science, Vol. 59 No. 2, pp. $420-435$.

Tan, K.C., Kannan, V.R. and Narasimhan, R. (2007), “The impact of operations capability on firm performance", International Journal of Production Research, Vol. 45 No. 21, pp. 5135-5156.

Tatikonda, M.V., Terjesen, S.A., Patel, P.C. and Parida, V. (2013), "The Role of Operational Capabilities in Enhancing New Venture Survival: A Longitudinal Study", Production and Operations Management, Vol. 22 No. 6, pp. 1401-1415.

Teece, D.J., Pisano, G. and Shuen, A. (1997), "Dynamic capabilities and strategic management", Strategic Management Journal, Vol. 18 No. 7, pp. 509-533.

Ulaga, W. and Reinartz, W.J. (2011), "Hybrid Offerings: How Manufacturing Firms Combine Goods and Services Successfully", Journal of Marketing, Vol. 75 No. 6, pp. 5-23.

Van de Ven, A.H. and Ferry, D.L. (1980), Measuring and Assessing Organizations, John Wiley \& Sons, New York, NY.

Visnjic Kastalli, I. and Van Looy, B. (2013), "Servitization: Disentangling the impact of service business model innovation on manufacturing firm performance", Journal of Operations Management, Vol. 31 No. 4, pp. 169-180.

Windahl, C., Andersson, P., Berggren, C. and Nehler, C. (2004), "Manufacturing firms and integrated solutions: characteristics and implications”, European Journal of Innovation Management, Vol. 7 No. 3, pp. 218-228.

Wu, S.J., Melnyk, S.A. and Swink, M. (2012), “An empirical investigation of the combinatorial nature of operational practices and operational capabilities: Compensatory or additive?", International Journal of Operations \& Production Management, Vol. 32 No. 2, pp. 121-155. 
Zeithaml, V.A. (2000), "Service quality, profitability, and the economic worth of customers: What we know and what we need to learn", Journal of the Academy of Marketing Science, Vol. 28 No. 1, pp. 67-85.

Zomerdijk, L.G. and de Vries, J. (2007), "Structuring front office and back office work in service delivery systems: An empirical study of three design decisions", International Journal of Operations \& Production Management, Vol. 27 No. 1, pp. 108-131. 
Figure 1: Conceptual model

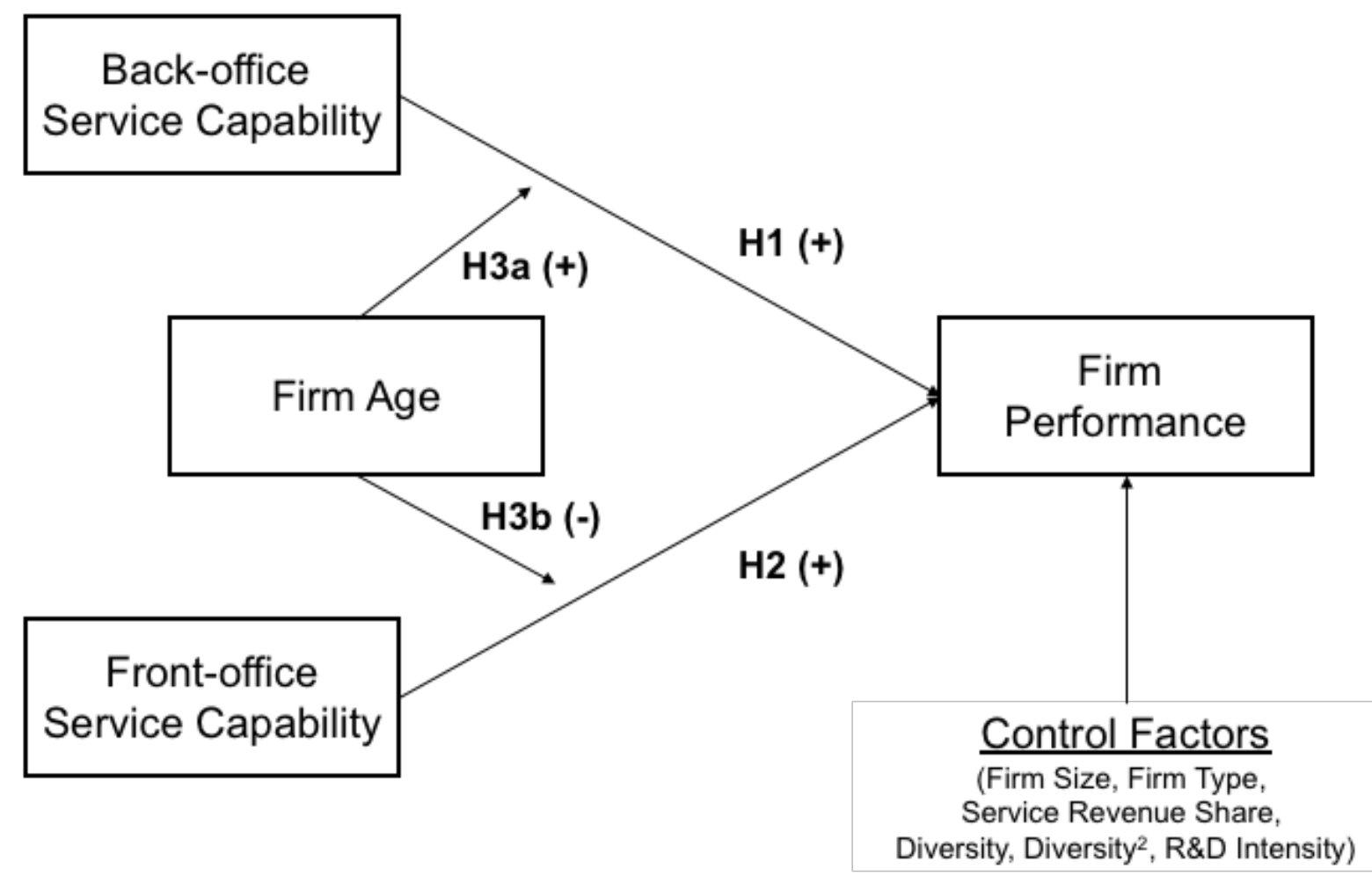


Figure 2: Plots of interaction effects

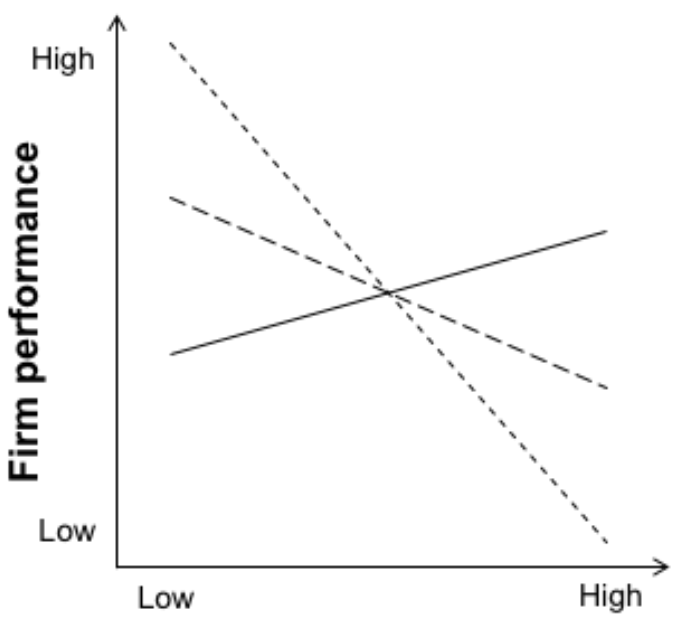

Back-office service capability

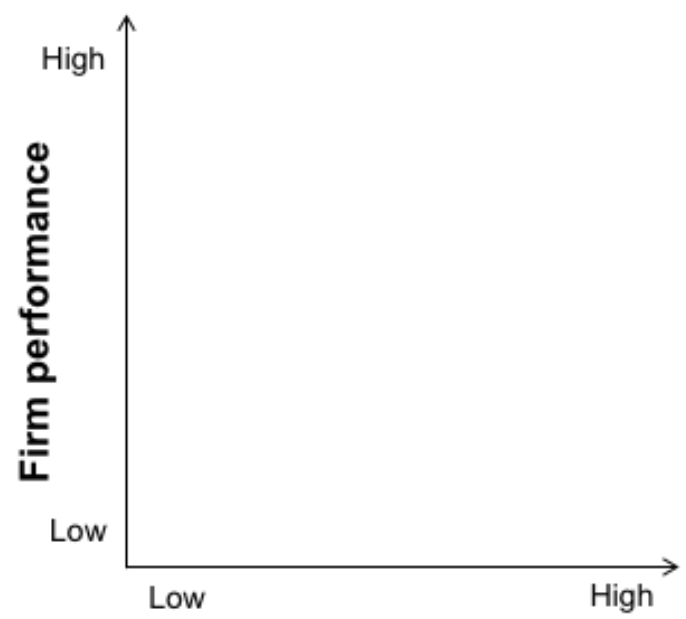

Front-office service capability

--- Younger firm - - Mean age _- Older firm 
Table 1

\begin{tabular}{lcccccc}
\hline Enterprise category & $\mathbf{N}$ & Employees & $\begin{array}{c}\text { Revenue } \\
(\mathbf{M} €)\end{array}$ & $\begin{array}{c}\text { Mean } \\
\text { Age } \\
\text { (years) }\end{array}$ & $\begin{array}{c}\text { Service } \\
\text { firm } \\
(\%)\end{array}$ & $\begin{array}{c}\text { Service } \\
\text { revenue } \\
\text { share (\%) }\end{array}$ \\
\hline $\begin{array}{l}\text { Micro } \\
\text { (<10 employees) }\end{array}$ & 120 & 4,9 & 0,47 & 9,2 & 53 & 59 \\
$\begin{array}{l}\text { Small } \\
\text { (<50 employees) }\end{array}$ & 84 & 22,0 & 2,17 & 11,1 & 55 & 62 \\
$\begin{array}{l}\text { Medium } \\
\text { (<250 employees) }\end{array}$ & 20 & 89,5 & 8,76 & 12,7 & 65 & 58 \\
& 224 & 18,9 & 1,85 & 10,2 & 55 & 60 \\
\hline Total & & & & & & \\
\hline
\end{tabular}


Table 2

\begin{tabular}{|c|c|c|c|}
\hline Variable & Definition & Source & Notes \\
\hline \multirow[t]{5}{*}{ BO Service Capability } & Four-item scale & Survey & standardized \\
\hline & (S1) We have precisely defined service processes & & centered \\
\hline & $\begin{array}{l}\text { (S2) We can forecast the usage of human resources } \\
\text { required by our services }\end{array}$ & & \\
\hline & $\begin{array}{l}\text { (S3) Our service documentation allows new employees } \\
\text { to quickly learn required skills }\end{array}$ & & \\
\hline & $\begin{array}{l}\text { (S4) The outcomes of our services depend strongly on } \\
\text { the delivering employees (reversed) }\end{array}$ & & \\
\hline \multirow[t]{5}{*}{ FO Service Capability } & Four-item scale & Survey & standardized \\
\hline & $\begin{array}{l}\text { (S5) It is easy for us to communicate with our } \\
\text { customers about our services }\end{array}$ & & centered \\
\hline & (S6) We find the pricing of services difficult (reversed) & & \\
\hline & (S7) We can maintain a constant level of service quality & & \\
\hline & $\begin{array}{l}\text { (S8) We can guarantee the success of our services to } \\
\text { our customers }\end{array}$ & & \\
\hline $\begin{array}{l}\text { ROS (Return on } \\
\text { sales) }\end{array}$ & Ratio of EBIT to total revenue & Orbis & \\
\hline Firm Age & Log(age in years) & Orbis & centered \\
\hline Firm Size & Log(total sales) & Orbis & \\
\hline Firm Type & Dummy variable for service firms & Survey & \\
\hline Service revenue share & Share of service revenue & Survey & centered \\
\hline Business diversity & 1 - sum(revenue shares squared) & Survey & centered \\
\hline R\&D Intensity & Ratio of $R \& D$ costs to total revenue & Orbis & winsorized \\
\hline
\end{tabular}


Table 3

\begin{tabular}{|c|c|c|c|c|c|c|c|c|c|c|c|c|c|}
\hline Variable & Mean & s.d. & Min & Max & Alpha & 1 & 2 & 3 & 4 & 5 & 6 & 7 & 8 \\
\hline 1 ROS & 0,08 & 0,18 & $-0,78$ & 0,84 & & & & & & & & & \\
\hline 2 BO Service Capability & 0,00 & 0,68 & $-2,28$ & 1,92 & 0,60 & 07 & & & & & & & \\
\hline 3 FO Service Capability & 0,00 & 0,78 & $-2,52$ & 1,56 & 0,67 & ,15 &, 30 & & & & & & \\
\hline 4 Firm Age & 0,02 & 0,76 & $-2,15$ & 1,37 & &, 07 &, 03 &, 04 & & & & & \\
\hline 5 Firm Size & 13,65 & 1,22 & 11,51 & 16,89 & &, 06 & ,11 & 09 & ,26 & & & & \\
\hline 6 Firm Type & 0,55 & 0,50 & 0,00 & 1,00 & & ,12 & ,21 & ,02 & , 18 & ,03 & & & \\
\hline 7 Service revenue share & 0,00 & 0,34 & $-0,57$ & 0,43 & & $\begin{array}{c}, 07 \\
-\end{array}$ &, 20 & $\begin{array}{c}, 07 \\
-\end{array}$ & ,20 & ,04 & $\begin{array}{c}, 70 \\
-\end{array}$ & - & \\
\hline 8 Business diversity & 0,00 & 0,25 & $-0,35$ & 0,43 & & 10 &, 12 &, 11 &, 30 & 15 &, 40 &, 56 & \\
\hline 9 R\&D Intensity & 0,16 & 0,17 & 0,00 & 0,69 & &, 27 &, 05 &, 05 &, 01 &, 16 &, 40 &, 37 & 22 \\
\hline
\end{tabular}

$N=224 ;$ Alpha = Cronbach's alpha

All correlations below -0.15 and over 0.15 significant at $p<0.05$ 
Table 4

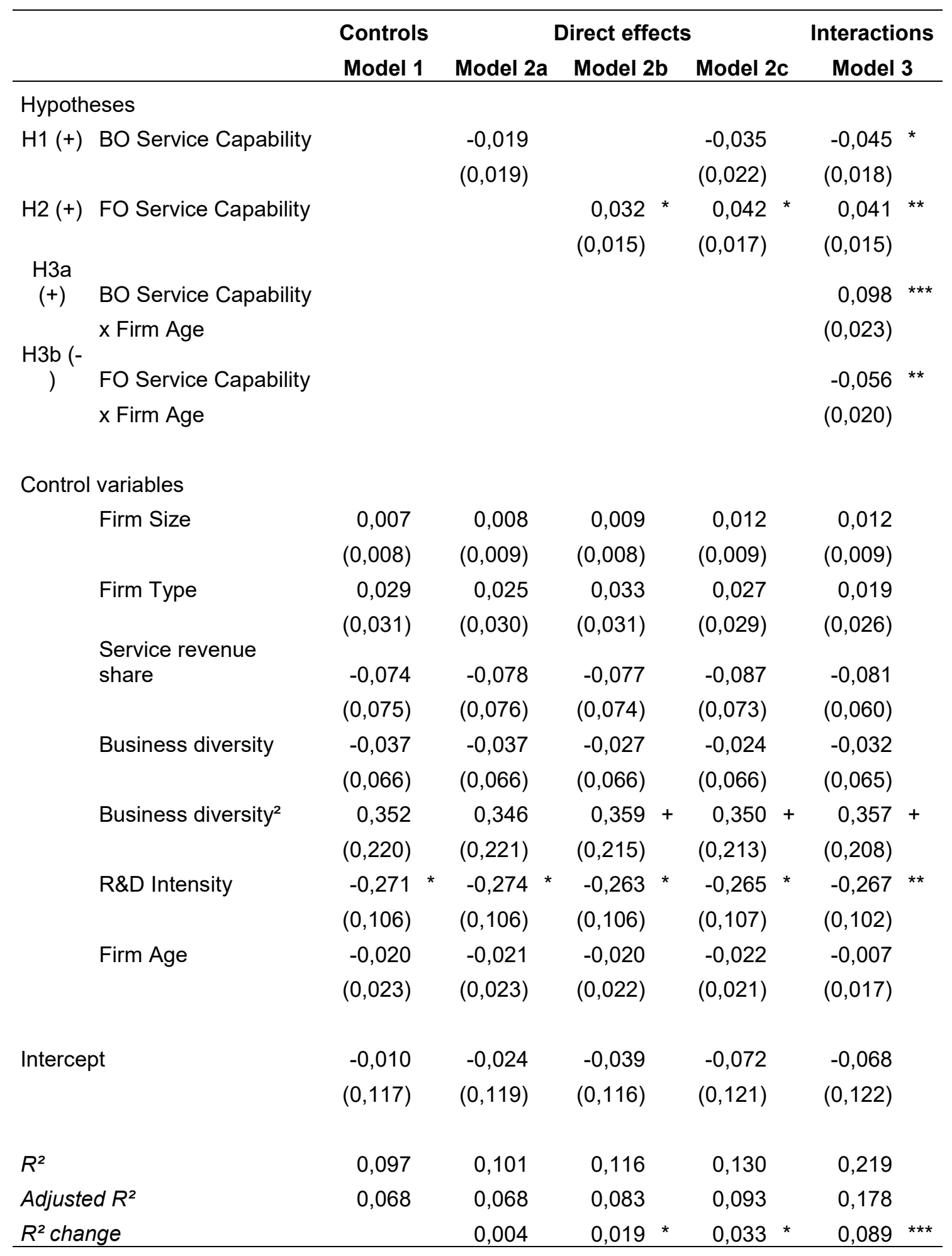

$\mathrm{N}=224$; s.d. values in parenthesis; $+\mathrm{p}<0.1$; $^{*} \mathrm{p}<0.05 ;{ }^{* *} \mathrm{p}<0.01$; ${ }^{* * *} \mathrm{p}<0.001$ 